\title{
Looking for Religious Logos in Singapore
}

Fischer, Johan

Published in:

Journal of Management, Spirituality \& Religion

DOI:

10.1080/14766086.2018.1470026

Publication date:

2019

Document Version

Peer reviewed version

Citation for published version (APA):

Fischer, J. (2019). Looking for Religious Logos in Singapore. Journal of Management, Spirituality \& Religion, 16(1), 132-153. https://doi.org/10.1080/14766086.2018.1470026

\section{General rights}

Copyright and moral rights for the publications made accessible in the public portal are retained by the authors and/or other copyright owners and it is a condition of accessing publications that users recognise and abide by the legal requirements associated with these rights.

- Users may download and print one copy of any publication from the public portal for the purpose of private study or research.

- You may not further distribute the material or use it for any profit-making activity or commercial gain.

- You may freely distribute the URL identifying the publication in the public portal.

Take down policy

If you believe that this document breaches copyright please contact rucforsk@kb.dk providing details, and we will remove access to the work immediately and investigate your claim. 


\title{
Looking for Religious Logos in Singapore ${ }^{1}$
}

\begin{abstract}
Within the last couple of decades, new types of religious logos have emerged. Notably, halal (in Arabic, halal literally means "permissible" or "lawful") logos are increasingly appearing on products, certificates, websites as well as in restaurants, shops, and advertisements globally. However, little empirical attention has been paid to these religious logos as elements of visual systems, or to their effects. This article fills that gap. I argue that religious logos are not well understood theoretically, conceptually or empirically and that they signify a new phase in logo development characterized by forms of religious regulation, certification, and standardization on a global scale. Building on empirical research on halal logos in Singapore, this paper shows that modern religious logos can fruitfully be explored at the interface between archive studies and ethnography.
\end{abstract}

Keywords: Logos, halal, Singapore, visual systems, archive studies, ethnography

\section{Introduction}

Global halal certified food and beverage trade in 2015 was estimated to $\$ 415$ billion and this figure is growing rapidly (Thomson Reuters 2016). The Koran and the Sunna (the life, actions and teachings of the Prophet Muhammad) exhort Muslims to eat the good and lawful that God has provided for them, but there are a number of conditions and prohibitions. Muslims are expressly forbidden to consume carrion, spurting blood, pork, or foods that have been consecrated to any being other than God himself. These substances are haram and thus forbidden. Ritual slaughtering entails that animals are killed in God's name by making a fatal incision across the throat. Another significant Islamic prohibition relates to wine and any other intoxicating drink or substance (Denny 2006). Because the sea is regarded as pure in essence, all marine animals, even if they

\footnotetext{
1 This article forms part of a research project (Fischer 2015), which explores how global halal (in Arabic, halal literally means "permissible" or "lawful") production, trade, and regulation are taking place. In that project, I examine halal state certification and standards in Malaysia and Singapore on the one hand, and businesses on the other. This article, however, focuses specifically on Singapore.
} 
have died spontaneously, are halal. To determine whether a foodstuff is halal or haram depends on its nature, how it is processed, and how it is obtained (Riaz and Chaudry 2004, 14). In the end, however, "the underlying principle behind the prohibitions remains Divine order" (Riaz and Chaudry 2004, 12).

In this context, a number of studies have demonstrated how emergent Islamic branding may differ from conventional branding (Alserhan 2010), and have highlighted the role of religious ideology among Muslim consumers (Izberk-Bilgin 2012). Similarly, Islamic marketing researchers have called for scholarship that moves beyond essentialist approaches to Muslim consumers and Islam more generally (Sand1kc1 2011), and for scholarship that focused on ethics in Islamic marketing (Arham 2010). Previous research on Islamic branding underlines how halal logos are connected to the modern Islamic economy, politics, and policies (Jafari 2012; Fischer 2008; 2011; 2015). It also puts forward how important logos are in consumer decision-making (Shafiq, Haque, and Omar 2015; Muhamad, Leong, and Md Isa 2017; Mohamed, Shamsudin, and Rezai 2013). The certification of halal products, and their labelling with logos, are essential in halal production, trade and regulation, because the halal-ness of products is not easily verifiable, and smell, texture, and/or taste cannot be used to determine whether a product is halal or not. Therefore, halal commodities and markets are no longer expressions of esoteric forms of production, trade, regulation and consumption, but part of a huge and expanding globalized market. In this rapidly expanding global market for halal products, Singapore and Malaysia hold a special position, as both are countries in which state bodies certify halal products, spaces (shops, factories, and restaurants) and work processes. In Singapore, Islam and halal are regulated by Majlis Ugama Islam Singapura or the Islamic Religious Council of Singapore (MUIS) and this creates a particular discursive and visual system of halal logos. 
The present research takes account of this specific Singaporean context to address how halal logos are promoted and managed, and the effect of these efforts on the marketplace and consumers. In particular, I argue that religious logos are not well understood theoretically, conceptually or empirically and that they signify a new phase in logo development characterized by forms of religious regulation, certification, and standardization on a global scale. The visual approach that is adopted in this paper allows me to move beyond existing research on halal (Bergeaud-Blackler 2007; Fischer 2008; 2011; 2015; Bergeaud-Blackler, Fischer and Lever 2015; Lever and Miele 2012) and to follow Johns (2006) and Jafari and Sandikci $(2015,2015)$ who call for more contextual research by focusing on how halal, as an element in various visual systems, shapes and is shaped by the local/national/global context, politics, and power.

This paper is divided into four sections. First, in a literature review, I provide elements of understanding of the theoretical and conceptual approaches to visual systems surrounding halal. I also suggest why and how halal logos are of special significance in Singapore. Second, I present how my research was conducted through archival analysis and ethnography. In the third section, findings underline that visual systems are contextual and thus have historical and political dimensions. In the same vein, I also stress that halal logos represent a new phase in logo development that is characterized by forms of religious regulation, certification, and standardization, while they also function as a localized form of Islamic branding in Singapore. Finally, the discussion section weaves the article's findings together and reflects on the emergence and expansion of logos within visual systems. 


\section{Literature Review}

\section{Islam and visual systems in context}

Visual systems are the processes that result in humans producing visible objects, reflexively constructing their visible environment, and communicating by visible means (Morphy and Banks 1998, 21). As a visual system, halal logos or marks can be studied as signs, in a field of design, which communicate the content of a message in its architectural setting (Sutton 1965). An urban environment such as Singapore is full of information, messages or directional signage (Gray 1960) and halal logos have thus become ubiquitous urban texts or guides for new kinds of public reading (Henkin 1998). In other words, these logos help to "letter" the environment (Baines and Dixon, 2003) while urban spaces and places provide settings for complex flows of information and the production of meaning (Mitchell 2005). In the case of Singapore, the state's involvement in designing and disseminating halal logos cannot be overestimated in reflecting the links between organizational issues of communication, culture, and control and the visual communication of identity in public (Lavin 2001).

Logos can be considered as signs that the sender uses to identify himself (Mollerup 1999). With regard to organic logos, for example, Laki (2016) shows that these are essential both for consumers and for the retail sector because they signify quality control. These logos are important sources of product-related information available to consumers (Parkinson 1975; Fischer 2011). This is a form of "logo logic" that works by attaching political and moral messages to lifestyle brands, and communicating these branded messages (Bennett and Lagos 2007). The design of halal logos systematically creates identifiable images through visual differentiation and consistency in national contexts (Large 1991). For instance, in 2003, Qatar commissioned a new graphic identity for the nation in the form of a logo that was intended to reinforce the history, values, religion, 
and language that Qatar shares with other Arab countries, as well as a commitment to progressive development that aligns Qatar with the West. However, it was not Qatar as a nation that was branded, but a marketing-driven nation-as-corporation, and this is quite similar to the case of halal logos in Singapore (Mattern 2008).

Organizational logos affect also the social construction of difference and authority, and shape how specific views or accounts of the world are warranted (Kurtz 2005). Writing and logos in public also fit into larger questions of the power involved in conveying order, clarity, and cleanliness in a messy reality. In this vein, standards and standardization may be regarded as instruments of control and forms of regulation attempting to generate elements of global order (Brunsson and Jacobsson 2000). The Singaporean state can impose sanctions on companies that do not live up to the expectations of halal standards. What is more, standards can also refer to persons with certain qualifications, knowledge, or skills (Brunsson and Jacobsson 2000) - for example, in Singapore it is mandatory for companies to set up a Halal Team in non-Muslim businesses. Busch (2000) argues that standards are part of the moral economy of the modern world that defines norms for behavior and creates uniformity. Standards standardize things or products: workers with regard to uniformity and discipline; markets in relation to fixed/uniform prices as well as the packaging of products; the ways in which capitalists behave and use capital; the standards themselves, that is, standardized methods that produce consistent results; the producers of standards such as scientists and technicians; consumers as a product of capitalist development and socially regulated consumption; and the environment.

Standardization can also be conceptualized as a move from a "bazaar economy" to a "standardized" economy (Fanselow 1990) characterized by substitutable commodities in terms of quality/quantity. In standardized consumer spaces such as McDonald's outlets 
and super/hypermarkets, a vast amount of information is transmitted via product logos and labels (Fanselow 1990). This form of standardized, impersonal shopping requires detailed information on labels and logos that signifies certification by a recognizable certifier. What is more, super/hypermarkets are themselves standardized spaces in terms of their design, which allows for the proper handling of halal on the one hand, and readiness for audits/inspections on the other. Therefore, an important theme is the emergence, consolidation, and expansion of an audit culture around halal commodities and practices; this also affects the shopping practices of ordinary consumers. Halal certifiers such as MUIS regulate halal by performing "on site" audits and inspections in factories, restaurants and shops. There is a large body of literature on the rise of the "audit society", but there is a need for further scholarship on religious audits and inspections and their implications for visual culture. Audit and inspection systems exist to generate comfort and reassurance in a wide range of policy contexts (Power 1999). To a large extent, auditing is about the cultural and economic authority granted to auditors (Power 1999). A central aspect of audit culture that is also highly relevant to the market for halal is the penetration of control and self-control further into organizations to satisfy the need to connect internal organizational arrangements to public ideals (Power 1999). Staff policies, and establishing sections in shops that specialize in halal, are examples of the increasingly prominent role of internal control systems that can be audited.

To sum up, the standards and standardization of visual systems can refer both to the design and qualities of products, and to the proper conduct of restaurants and shops. Halal standardization represents a particular take on how Singapore is situated at the intersection of a range of interlocking forces: local economies of consumption and a globalizing halal industry; religious principles and administrative practices; the country's economic ambitions and the experiences of market actors. 


\section{Singapore and halal}

Singapore is highly urbanized, and even if a visual culture of halal is most prominent in Singapore's major shopping/dining areas around Orchard Road, halal logos can be found throughout the country. Singapore is a Chinese majority country, while Muslims - who are largely ethnic Malays - constitute the largest minority, and this has a significant bearing on halal production, trade, consumption, and regulation. Out of 3.77 million Singapore residents in 2010, the Chinese comprised about 74 per cent, Malays 13 per cent and Indians nine per cent, while Others accounted for the remainder. ${ }^{1}$ Singapore exists in a double minority setting: Chinese are a majority in Singapore but a minority in the region, whereas Malays are a minority in Singapore but a strong majority in the immediate region (Mauzy and Milne 2002). This complex relationship is essential to understanding halal in Singapore. Singapore's colonial history dates back to 1819 when the British East India Company chose it as a settlement because it was centrally located for trade. In 1959, the People's Action Party (PAP) formed a government, led by Lee Kuan Yew, who was the first Prime Minister of the Republic of Singapore. Lee governed for three decades until 1990 and he can be said to have been the architect behind Singapore's impressive performance and continuous economic growth.

The state promotion of halal in Singapore presents a paradox: halal as an ancient Muslim food taboo is promoted as a national and neutral brand that benefits the economy, while the moral implications are downplayed - especially in a Chinese majority cultural context where Chinese social, religious and economic rituals are unavoidably intertwined. It is in this context that Malay Muslims are called upon to handle halal properly. In other words, no matter how forcefully halal is promoted as a highly lucrative global market in which countries such as Singapore want to find their rightful place, halal is essentially an Islamic moral injunction and not socially neutral in nature. Before halal became part of a 
global and growing market, the Singaporean state considered it an expression of excessive religiosity and minority rights that separated Muslims and non-Muslims in a multiracial context.

Singapore is outspoken on the international stage in support of moderate Islam in the context of the Shafi'i school of Sunni jurisprudence in a secular state framework. Islam is heavily state regulated in Singapore. MUIS is the state Islamic institution and its main decision-making body is a council headed by a President. It also comprises the Mufti of Singapore and members nominated by Muslim organizations. The state in Singapore promotes religiosity even though Singapore is officially a secular state, that is, the religious economy is heavily regulated and governed by a very pragmatic state (Pereira 2005). When the Administration of Muslim Law Act (AMLA) was enacted in 1965 it allowed for the establishment of MUIS in 1968 and the consequent culmination of the fusion of Malay and Muslim identities in Singapore (Kadir 2004, 360). The management of Islam in Singapore is conducted through the institutionalization of AMLA, and through MUIS, which was founded in order to administer matters relating to the Muslim religion and Muslims in Singapore, including any matter relating to halal certification. ${ }^{2}$ MUIS started to provide halal services in 1972, and the first halal certificate was issued in 1978. MUIS is solely responsible for this task, and performs a regulatory halal function on behalf of the state. MUIS also facilitates the halal food trade through certifying local exporters to export their products to the global halal market; certifying local establishments; and participating in forums on the standardization of halal certification (Riaz and Chaudry 2004).

An amendment of AMLA was passed in 1999, giving MUIS new powers to regulate, promote and enhance the halal business. This bill endows MUIS with the sole authority to regulate the halal certification of any product, service or activity in Singapore. 
On 1 December 2009, a further amendment of AMLA took effect, with specific reference to halal certificates, so that it became a serious offence to display false halal logos, that is, false MUIS logos. On MUIS' website, its halal services are described as follows:

MUIS is vested with the powers to act as the sole authority to administer and regulate Halal certification in Singapore. This is clearly stipulated in AMLA:

Section $88 \mathrm{~A}(1)$ : The Majlis may issue Halal certificates in relation to any product, service or activity and regulate the holders of such certificates to ensure that the requirements of the Muslim law are complied with in the production, processing, marketing or display of that product, the provision of that service or the carrying out of that activity.

Section 88A(5): Any person who, without the approval of the Majlis a) issues a Halal certificate in relation to any product, service or activity; or b) uses any specified Halal certification mark or any colorable imitation thereof, shall be guilty of an offence and shall be liable on conviction to a fine not exceeding $\$ 10,000 \ldots$ or to imprisonment for a term not exceeding 12 months or both. ${ }^{3}$

In the Singaporean context, halal evolved from being a sensitive Malay minority question to becoming a major national state and market focus. Singapore's double minority setting has been a driving force in the promotion of halal — Malay Muslims are simultaneously seen as a problem as well as instrumental in the production, promotion, regulation and consumption of halal. The stress on Chinese ethnicity, ethics and values also embodies a powerful narrative about the hard-working and economically successful Chinese who must tap into the expanding global market for halal. All this takes place in the framework of Singapore's unique form of government that can be characterized as a kind of authoritarianism that allows for close networking between key organizations and institutions, but also enforces a standardized audit culture around the commoditization of halal. MUIS as a statutory body plays a pivotal role in regulating the halal market in Singapore. 


\section{A note on methodology}

This research is based on the combination of archival analysis and ethnography conducted in Singapore. Over the past three decades, the state in Singapore has effectively certified, standardized, and bureaucratized halal production, trade, and consumption, with the aim to play a leading role in the global Muslim market, especially vis-à-vis neighboring Malaysia and Indonesia. This has had a profound effect on the everyday experiences of consumers, companies, and regulatory institutions in the country. These transformations have also had a great impact on the emergence and proliferation of halal logos as elements in visual systems and thus also marketing and management. Also Singapore is the perfect place to look for halal logos, since the Singaporean state asserts its power and communicates through signage (Zhuang 2009).

Methods employed in this study rests on two interlinked approaches to studying halal logos in Singapore: archival analysis and ethnography. Regarding archives, I retrieved articles from the country's major newspaper, namely The Straits Times (ST), which was established in 1845 . This newspaper is censored and it expresses state ideology as well as the political discourse and control of the People's Action Party (PAP), which is the dominant political party in Singapore. Articles on halal in The Straits Times are cultural texts in which the state and "the public" are represented (Gupta 1995). My reading of newspapers involved a historical ethnography of halal understandings and practices in a particular setting that "reciprocally shape subjects and contexts, that allow certain things to be said and done." (Comaroff and Comaroff 1992, 31). I looked for halal logos as keywords (Williams 1976, 24), that is, as "an exploration of the vocabulary of a crucial area of social and cultural discussion, which has been inherited within precise historical and social conditions". Most articles could be retrieved in electronic form, but 
older ones from the 1970s could not. Thus, different archives required different access strategies (Burton 2006).

Ethnography was conducted in Singapore between 2009 and 2010 among religious authorities, companies, shops, and restaurants. I paid particular attention to, and took photographs of, the way in which halal logos (Figure 1) in Singapore are or should be displayed in order to live up to legal/religious requirements. A specific question in this respect was how companies negotiate the placement of logos on products, production space, advertisements, certificates, and websites with the certifying bodies. Thus, I studied the properties of halal within a framework of visual systems and the conditions of their interpretation, and I related these particular systems to the complexities of which they are a part (Morphy and Banks 1998). I looked for halal logos in Singapore by building on a contextualized, historicized, and spatialized perspective informed by broader national processes such as local politics, power struggles, and competing claims to space (Leeman and Modan 2009). During fieldwork in restaurants and shops, I followed the people (staff responsible for halal compliance); the thing (halal commodities with logos as manifestly material objects of study) (Marcus 1995, 106) as well as the metaphor (halal embedded in particular realms of classification, discourse, and modes of thought) (Marcus 1995, 108). Thus, I combine extensive archive studies and ethnography to show the emergence, consolidation, and expansion of halal as an element in discursive and visual systems in Singapore. 


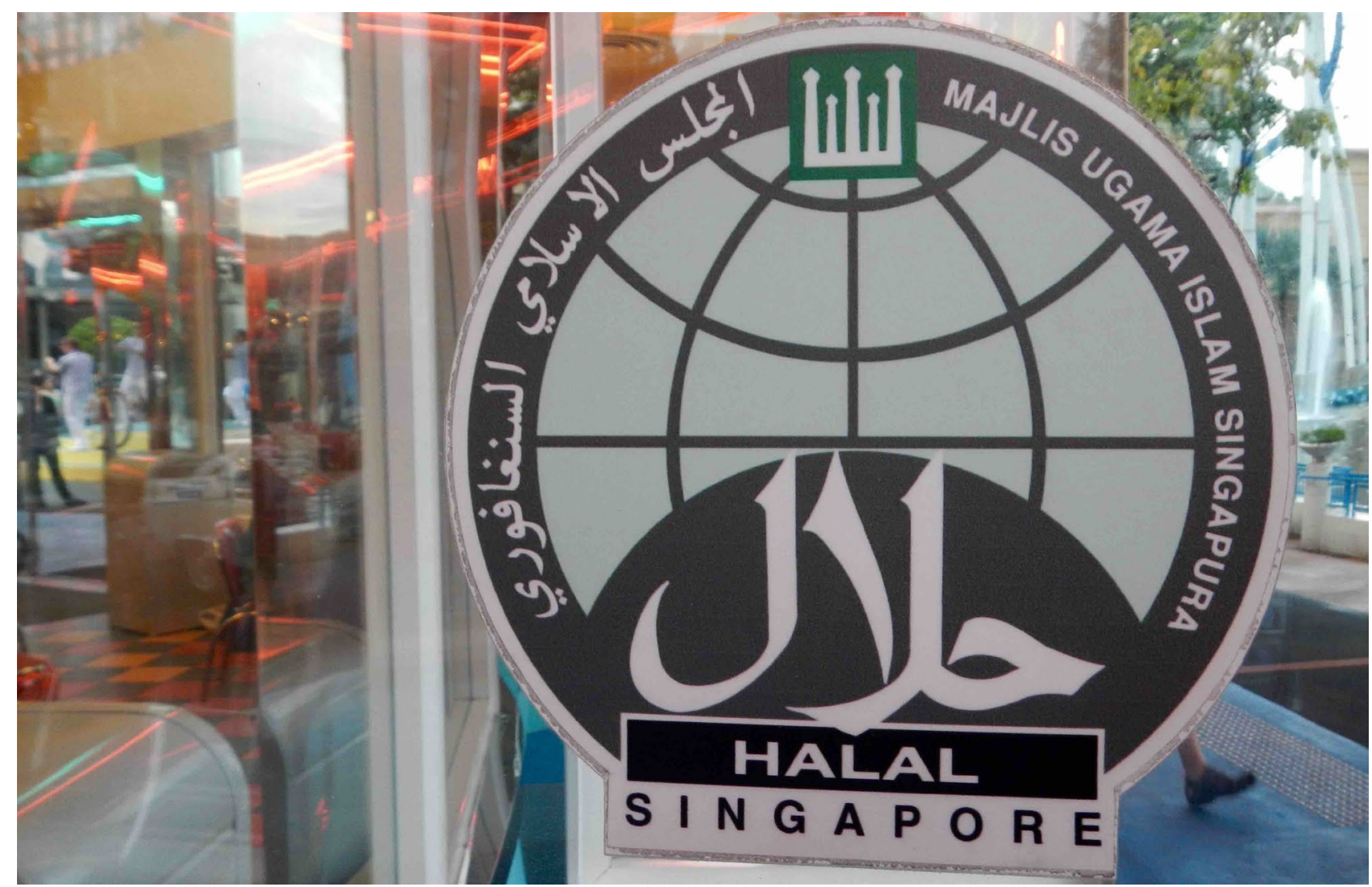

Figure 1: The MUIS halal logo on a restaurant door.

\section{Findings}

\section{Historic context of halal logos in Singapore}

The enforcement of state halal certification and logos is a favorite topic in the Singaporean media. As early as 1978, the year when the first MUIS halal certificate was issued, MUIS stated that it would not hesitate to prosecute any firm for willfully deceiving Muslims by putting up misleading and deceptive products for sale. Firms and manufacturers intending to classify their products as halal had apply to MUIS for a certificate before putting their products on the market (The Straits Times, March 23, 1978). After MUIS established national Singaporean halal certification in 1978, the discourse surrounding halal began to focus on the multiplicity involved in regulating and enforcing this type of visual standard. For example, MUIS asked a fast food restaurant 
that claimed to have halal certificates to explain itself; MUIS' public relations officer argued that having halal certificates for slaughter did not make the restaurant halal (The Straits Times, July 3, 1981). MUIS now conducts its own investigations into restaurants and food stalls exhibiting halal logos indiscriminately (The Straits Times, November 12, 1985). As these points demonstrate, as an organization MUIS was rationalized to develop and refine halal regulation based on logos.

The People's Action Party (PAP), a political party in Singapore, launched a new series of dialogue sessions to gather feedback on issues affecting the Malay Muslim community. A key issue that arose was the use of false halal logos by some restaurants and hawkers (The Straits Times, May 30, 1991). This point relates to the way in which halal discourse intensified in the early 1990s. A central theme in this was the proliferation and regulation of halal into more and more areas, for example through MUIS certification of abattoir poultry (The Straits Times, May 23, 1992). When abattoirs apply for halal certification they must now comply with MUIS requirements and ensure that they have enough Muslim workers to comply with their guidelines, since only Muslim staff can attach the halal logos (The Straits Times, July 12, 1992). This is an important point because it testifies to the trend that Muslims must be involved in the proper handling and display of logos, and not only the actual ritual slaughter, due to increasing halal requirements. Another important issue here is how techniques and technologies of certification and logos form part of visual systems. When the move from wet market to abattoir slaughter was completed, logos in the form of paper tags would tear when wet and had to be replaced by stallholders, with some poultry hawkers in wet markets resorting to do-it-yourself tagging. As a result, hawkers called for waterproof plastic or aluminum tags to be used instead. In these markets, stallholders must only sell poultry labelled by the abattoirs. The penalty for not doing so is a fine of up to $\mathrm{S} \$ 1,000$ for the 
first offense, and S\$2,000 for the second and subsequent offenses (The Straits Times July, $16,1992)$

An important theme is the fact that MUIS dissatisfaction with the licensing of halal food is not backed by legislation. The rationale here is that as long as the vendor is a Muslim, regardless of race, the onus of ensuring that the food served is halal rests with them, as MUIS has no legislative powers to stop any halal restaurants from operating or to subject them to a test or inspection (The Straits Times, June 29, 1992). A particular case relates to the Muslim handling of halal in a seafood restaurant listed as a non-Muslim owned restaurant without a halal certificate. MUIS had to clarify that this was incorrect and that the restaurant was Muslim-owned and thus did not need to apply for a halal certificate at that time (The Straits Times, July 13, 1992). Another seafood restaurant was reported by customers for promoting itself as halal in an advertisement while not displaying a MUIS halal logo (The Straits Times, May 13, 1994).

From the mid-1990s onwards, discourse about halal focused on calls to tap the growing global market for halal production, trade, and consumption through MUIS certification; that is, from around that time the state and companies in Singapore realized that halal had grown into a truly global market with immense business potential. In 1994, Singapore's exports of halal food amounted to S\$1.2 billion, making up 24 percent of the country's total food and beverage exports of S\$5 billion (The Straits Times August 17, 1995). In 1995, MUIS introduced its first logo, with the aim of standardizing existing logos used to label halal food products. Previously, food manufacturers with halal certificates had merely used the Arabic halal symbol to indicate that their food was halal, and not a standard logo. Food manufacturers now had three months to change their halal logo to the new one issued by MUIS (The Straits Times, August 21, 1995). Thus, centralized regulation transformed diverse classifications of logos into one national 
standard. With the amendments to the Administration of Muslim Law Act (AMLA), MUIS' role as the highest Islamic authority in Singapore was expanded and strengthened, and MUIS was entitled to form part of companies as well as joint ventures. Moreover, MUIS was given the authority to issue halal certificates and punish those who violated the rules (The Straits Times, April 1, 1998).

In the late 1990s, discourses about halal focused on the success of halal certified companies and, thus, logos. MUIS reported a steady increase in issued halal certificates. The certificates were said to attract business because Muslims were assured that their food was halal, especially in Malay areas. Supermarkets, including NTUC FairPrice as we shall see below, set up halal sections and reported increased sales - including customers from Malaysia crossing the Causeway to shop. This success reinforced MUIS requirements that companies have to pass stringent checks before they are given the certificates. Food must be prepared properly for Muslim consumers and companies must use equipment free from contact with non-halal food. A coordinator from a certified catering firm explained that this process was not easy - the firm had spent about $\mathrm{S} \$ 4,000$ to restructure the kitchen and had had to look for new halal suppliers, but in the end it had profited from these changes (The Straits Times, September 25, 1999).

With the massive proliferation of halal certification and markets came new calls for reviewing halal certification laws. When firms misuse halal certificates or logos, they are merely fined, but individuals who do the same thing face jail because the law prosecutes the company and not its staff. This should be changed, a High Court Judge argued. This call appeared in the wake of a court case where a Singaporean company had used MUIS' halal logo on chicken nuggets imported from Thailand. The product was, in fact, halal, but the company had used MUIS' logo without its approval (The Straits Times, September $13,2006)$. 
MUIS wanted a more rigorous scheme for certifying products as halal that would help local companies to market products overseas. In 2007, the global halal market was estimated to be worth more than US\$2.1 trillion. The new certification scheme developed by MUIS was called the Halal Quality Management System or HalMQ (pronounced hallmark) and it took effect on March 1, 2008. Suppliers going for certification for the first time had to comply with all HalMQ terms from this date and existing holders of halal certificates had until January 1, 2010 to comply. While the previous halal certification requirements were product focused, the new certification scheme went further and set standards for business operations, in addition to ensuring that the ingredients and the preparation of food or health goods were halal. HalMQ required companies to appoint people to monitor and document the preparation of halal products and recommend corrective actions if products were tainted by alcohol or other prohibited ingredients (The Straits Times, November, 14, 2007). The proposed changes to AMLA aimed to give halal certification laws more clout and provide MUIS with more leverage in supervising and enforcing halal certification at a time when the global halal food industry and exports to Middle Eastern markets were growing. The new law also aimed to resolve an anomaly in the current law so that individuals who misused halal certificates are liable to a jail term, but companies that do the same thing are only liable to fines (The Straits Times, September 16, 2008).

Since the issuing of MUIS' first halal certificate in 1978, some major transformations have occurred in the realm of certification, logos, and legislation. Halal logos have become keywords in global markets, and certificates/logos play increasingly important roles. What is more, since the early 1980s, Singapore nationalized and standardized the proliferation of halal and concentrated its certification in the realm of the state and MUIS, where it has remained. 


\section{Halal logos and restaurants}

I now turn to how halal logos form part of visual systems in restaurants: fast food chains such as McDonald's, independent restaurants and food stalls. Actually, the emergence of halal logos as elements in visual systems in restaurants and shops may be regarded as an example of McDonaldization, that is, processes by which the principles of the fast-food restaurants are coming to dominate more and more regions of the world, affecting education, work, politics, religion, and many other aspects of society (Ritzer 2006, 5) such as visual systems. Arguably, McDonald's has succeeded because it offers consumers, workers and managers efficiency, calculability, predictability and control (Ritzer 2006, 14) and that is also the case with the way in which halal has been standardized in the company. In countries such as Singapore and Malaysia, McDonald's has adopted halal logos in outlets and advertisements, creating a form of McDonaldization of visual systems. In Singapore, McDonald's underwent rigorous inspections by Muslim clerics to ensure ritual cleanliness, and these restaurants are fully halal certified (Watson 2006). In the popular media in Singapore, restaurants and rising halal requirements and concerns started to surface in the early 1980s. MUIS clarified that Muslims are forbidden to eat meat at restaurants without halal certificates. At the same time, Kentucky Fried Chicken (Figure 2) was "looking into" setting up halal chicken branches in areas with many Malays. In 1981, KFC burgers were "pork-free" but the meat was not prepared the "Muslim way".

In 1992, McDonald's (Figure 3) was fully halal certified by MUIS: the slaughtering of animals, preparation of food and cleaning of utensils all have to be done by Muslims; two Muslim employees must be present to verify the halal status of the food at all times; and MUIS must be allowed to carry out spot-checks to ensure that standards are observed 
(The Straits Times, August 27, 1992). Restaurant owners, including McDonald's, mainly become certified to expand their customer base among the local Muslim population.

When Burger King (Figure 4) was halal certified in 1996, not only was pork bacon replaced by turkey bacon, restaurant outlets also had to undergo ritual cleansing (The Straits Times, June 25, 1996). However, using halal turkey ham and bacon was confusing to some Muslim consumers, who contacted MUIS (The Straits Times, April 23, 1997). In subsequent years, more and more restaurants, such as Pizza Hut, were halal certified and many had to undergo ritual cleansing. In Singapore, a Chinese owner of a restaurant that specializes in Indonesian cuisine employs Muslim workers, and the menu does not contain pork. He explains that he had no choice - he had to become halal certified and put up a halal sign (Zainal 2009). Other restaurant owners likewise reveal that they attract more Muslim customers after becoming halal certified. Another restaurant owner explained that this was a tedious ritual but that it had to be complied with. Many Chinese and other types of restaurants also became halal certified (Figure 5) and a similar process can be seen with food stalls (Figure 6).

Above, I have traced the ways in which restaurants and advertisements have been labelled with halal logos in Singapore. Halal logos and certificates play major roles in standardized restaurants selling standardized halal products. Standardization renders halal impersonal, and, in turn, this stresses the need for third party visual assurance, which also has legal implications. 


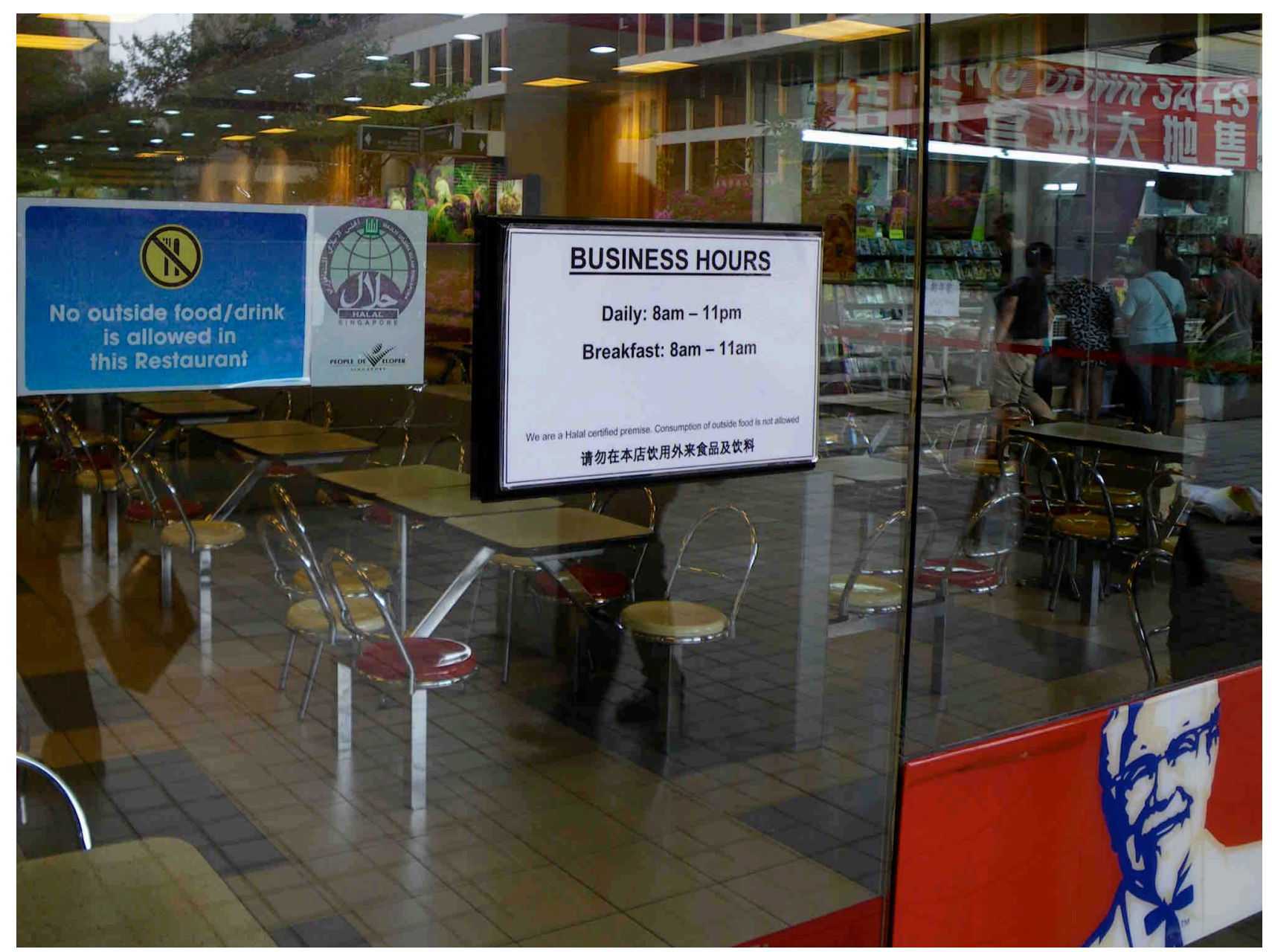

Figure 2. KFC. 


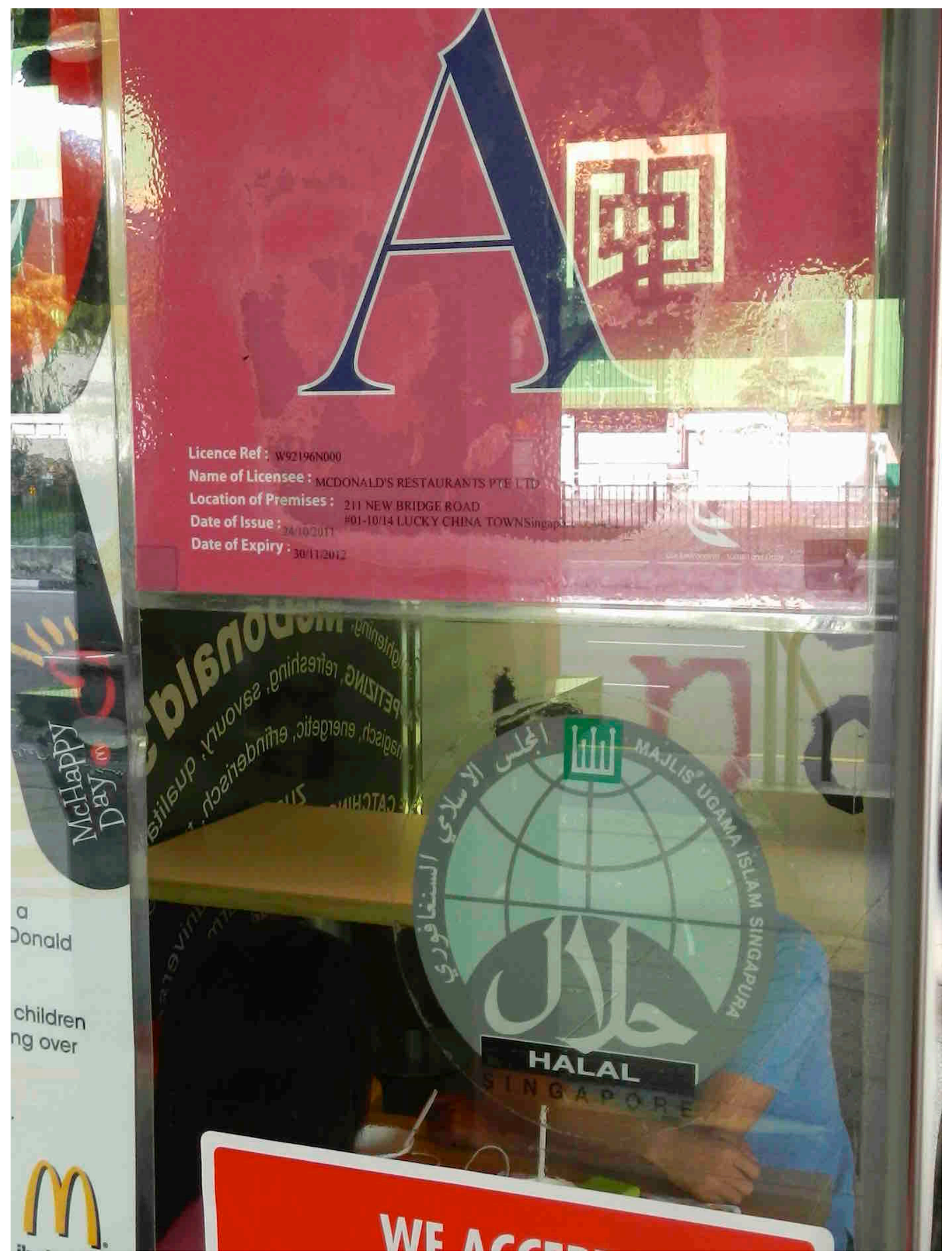

Figure 3. A McDonald's outlet in Chinatown. 


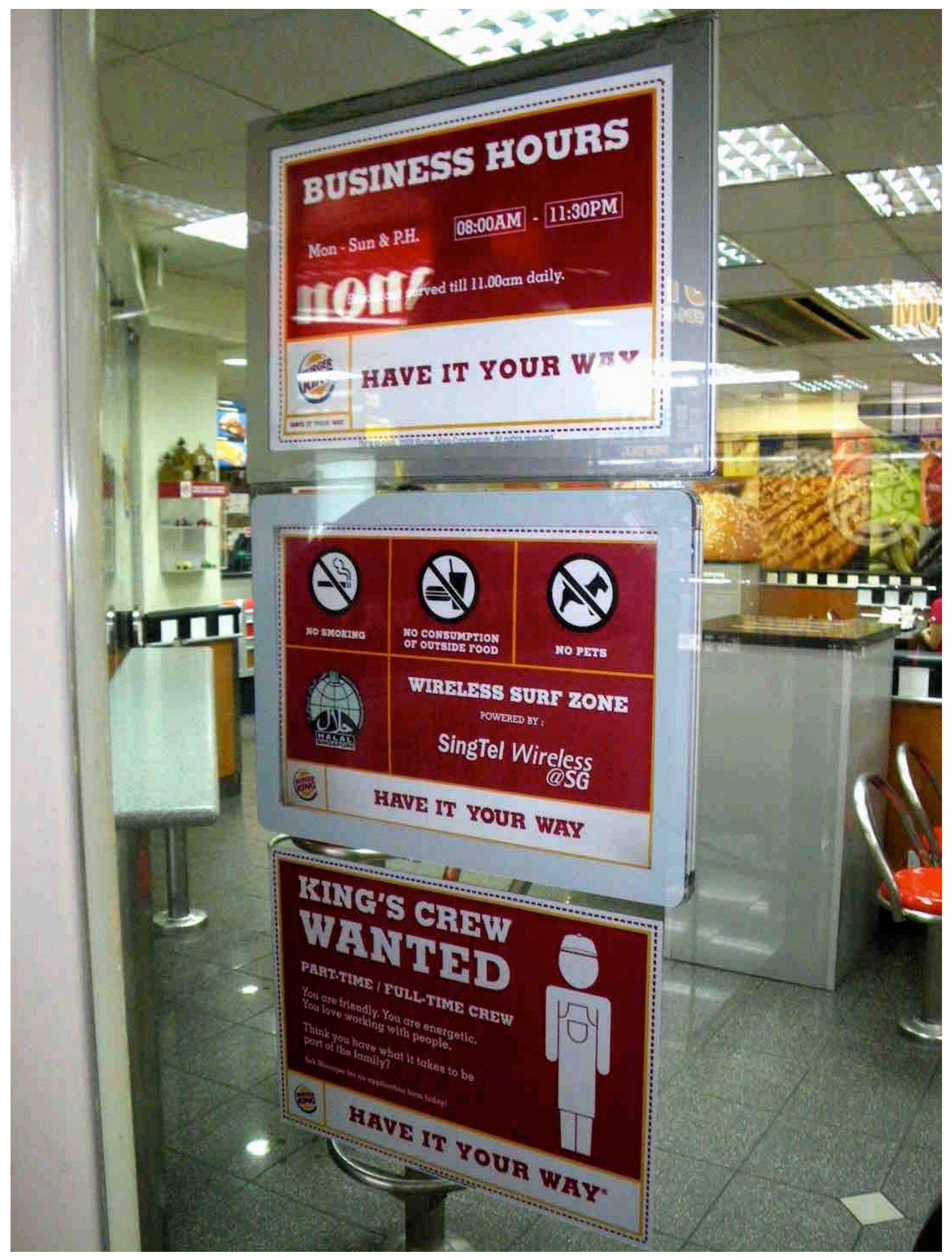

Figure 4. Burger King. 


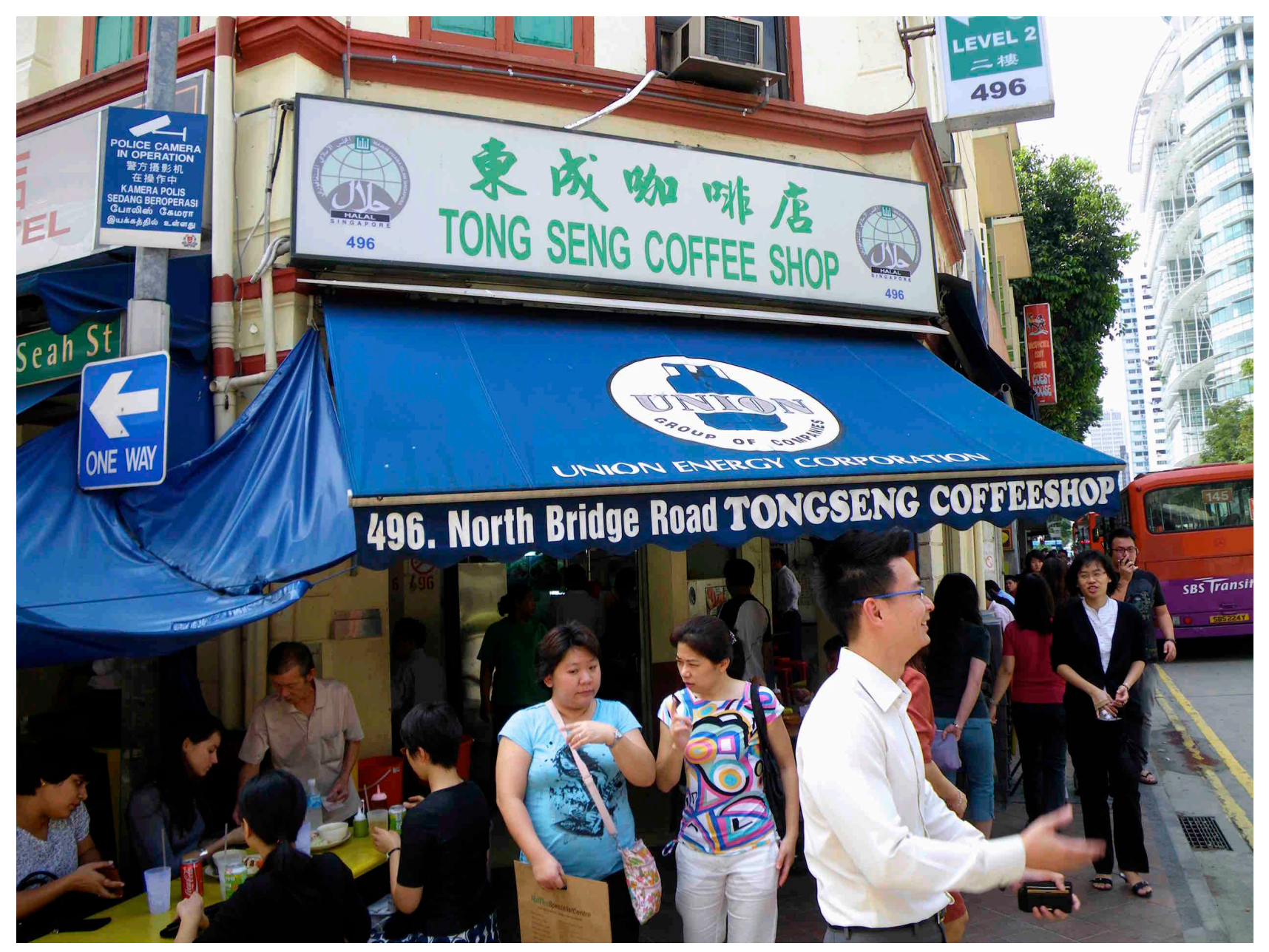

Figure 5. A Chinese coffee shop. 


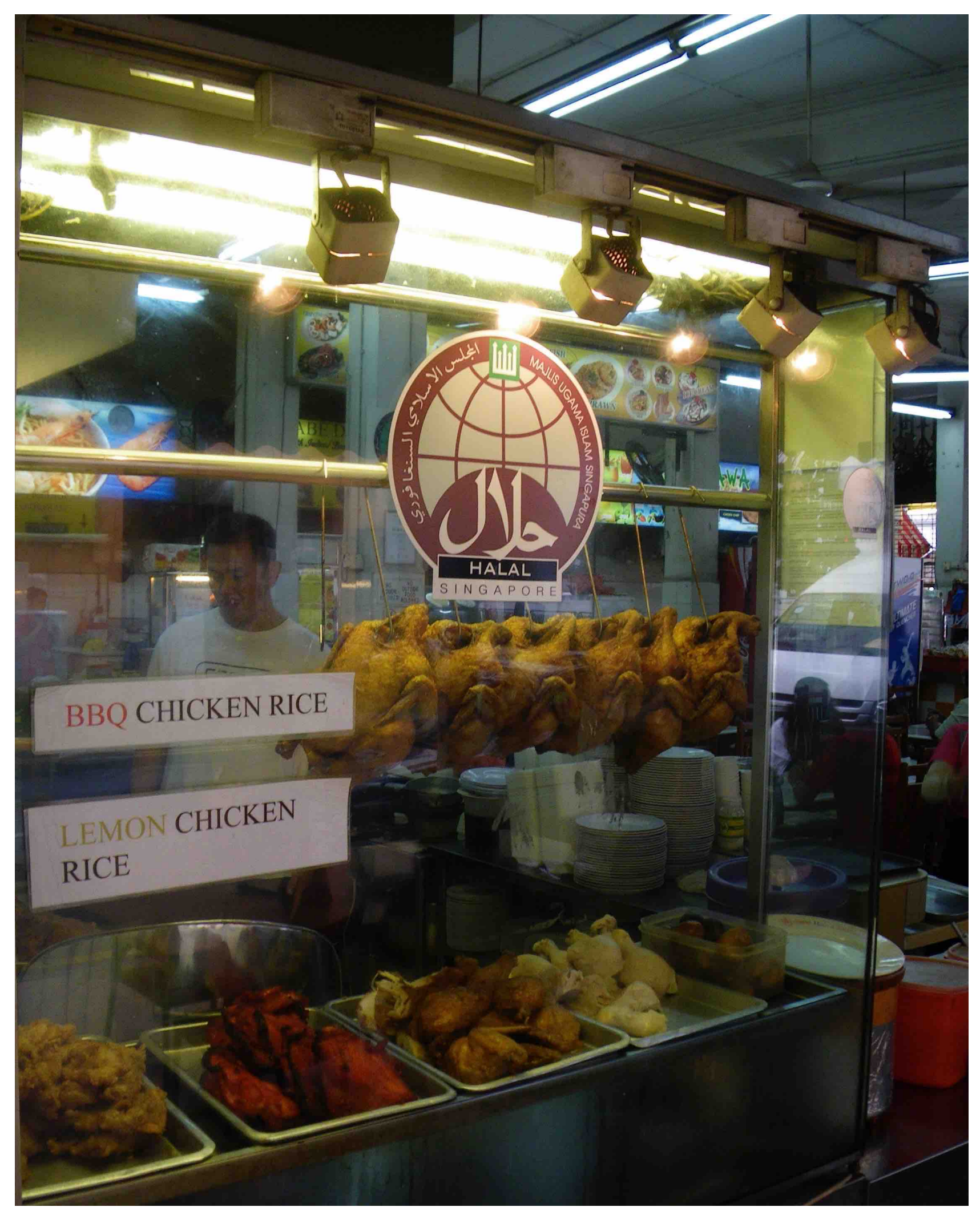

Figure 6. A food stall. 


\section{Halal logos and stores: the case of FairPrice}

FairPrice stores were set up in the 1970s by the NTUC (National Trade Union Congress) Welcome Consumers' Cooperative Ltd. FairPrice has since evolved into Singapore's biggest grocery retailer. In a news release in 2009, FairPrice announced Singapore's first supermarket audited by a local halal consultancy organization at Joo Chiat Complex in Eastern Singapore (NTUC FairPrice 2009). This supermarket aimed to address the needs of Muslim customers by introducing a wider range of halal-certified offerings within its store, catering for the significant Muslim population residing in the vicinity of the store. FairPrice at Joo Chiat Complex was the first supermarket to appoint a local halal consultancy organization, the Chairman of NTUC FairPrice announced. Moreover, FairPrice had plans to extend this to other, bigger stores.

During fieldwork I met a FairPrice Director of Food Safety \& Quality. FairPrice received its first ISO (International Standards Organization) certificate in 1993 and HCCP (Hazard Analysis and Critical Control Points) certification around the same time. According to the Director, these types of certification serve as "everyday platforms and procedures for standardization and standardized practices in all Fairprice outlets". In around 2006, FairPrice started to receive more and more requests about halal from Muslim customers, and as a cooperative it was necessary to address all needs from organic to halal, but the question was how to do it: "There has to be a mindset in terms of a system." Halal has become increasingly important for FairPrice, and the organization has tried to focus on "mass requirements" and "streamline basic platforms" to address issues such as everyday standard operating procedures for doing things.

FairPrice designs all the packaging for their own brands (Figure 7) and also takes into account how the MUIS halal logo fits in with the general design of their house brand products. The Director explains that the packaging is designed so that it is "suitable" for 
all Singaporeans. Many products carry the nutritional information required under the Sale of Food Act, which is at the top of the label. Below that is the Healthier Choice Symbol issued by the Health Promotion Board under the Singaporean Government. Under this logo is the MUIS halal logo. The FairPrice design department is, to a large extent, responsible for these designs, and MUIS and other parties are flexible about it. However, MUIS does not accept red logos, for instance, preferring green or black ones. The process behind the halal logo on specific packaging is as follows: the supplier applies for the halal certificate and normally it takes between 9-12 months for the final approval to go through. When the supplier receives the logo from MUIS this is sent to FairPrice, which fits it into the overall design of the packaging.

Having the MUIS halal logo on products helps FairPrice when consumers enquire about the halal status of products. At the same time, industry players in Singapore and MUIS are aware of the growing demand for halal-certified products together with increased competition from Malaysia and elsewhere. FairPrice finds itself at the interface between industry, consumers and MUIS, which is why it takes halal so seriously. During my fieldwork in Singapore, I found a wealth of different halal logos in FairPrice outlets: a MUIS logo on a bag of honey almonds together with a number of other logos; a MUI (The Majelis Ulama Indonesia or Indonesian Ulemas Council) halal logo on coffee; and many other halal logos. In FairPrice, as in other super/hypermarkets in Singapore, most (food) products are halal certified.

After the FairPrice Halal Quality Management system was established in 2010, the organization fully complied with MUIS' halal standard requirements - for example by setting up a halal counter (Figure 8). The management system of the Food Safety and Quality Department in FairPrice also involves audits at suppliers and food safety partners along the supply chain. More specifically, the "building blocks" for this Halal Quality 
Management System include "commitment" as the management has endorsed a Halal Quality Policy; standards based on MUIS halal standards; ISO 9001 (deals with the requirements that organizations wishing to meet the standard have to fulfil) and HACCP; and audit programs in relation to suppliers, warehouses, HQ and all supermarket outlets. The Operational Halal Integrity Program, which FairPrice set up, ensures that halal control points are properly monitored at the stores by focusing on three key areas. Specifically, each store is designed so its layout can be properly reviewed in order to ensure: minimal cross-contamination; product control which streamlines the list of halal certified products versus non-halal products with regard to store layout and population needs; and facility/equipment control. FairPrice set up the mandatory Halal Team that attends to halal training. I carried out participant observation at halal training sessions, where one of the key topics was the significance of halal logos and their placement. Before this became a mandatory requirement, it was just, in the words of the Director, a "working team". Every FairPrice outlet with a halal certificate had to send one staff member for training. This training was constructive for FairPrice in that it laid out the basic MUIS "halal principles, standards", the Director explained to me: "If we know that these are the mandatory standards then it's easier to talk to the officers and inspectors and to form our own system." In addition to the above, employees at FairPrice must participate in an on-the-job-training program to ensure that staff are apprised of how to receive, handle, and display halal certified products. Finally, the organization has a communication program including various platforms with suppliers, staff and customers to ensure all parties are aware of the proper handling of halal certified products.

In conclusion, the FairPrice case shows how an organization can comply with increasing halal requirements and how logos play an essential role in these processes. This can be challenging at times, but by now the entire process has been "standardized", 
meaning that in supermarkets the roles of and relationship between MUIS as a regulatory institution and FairPrice have been settled.

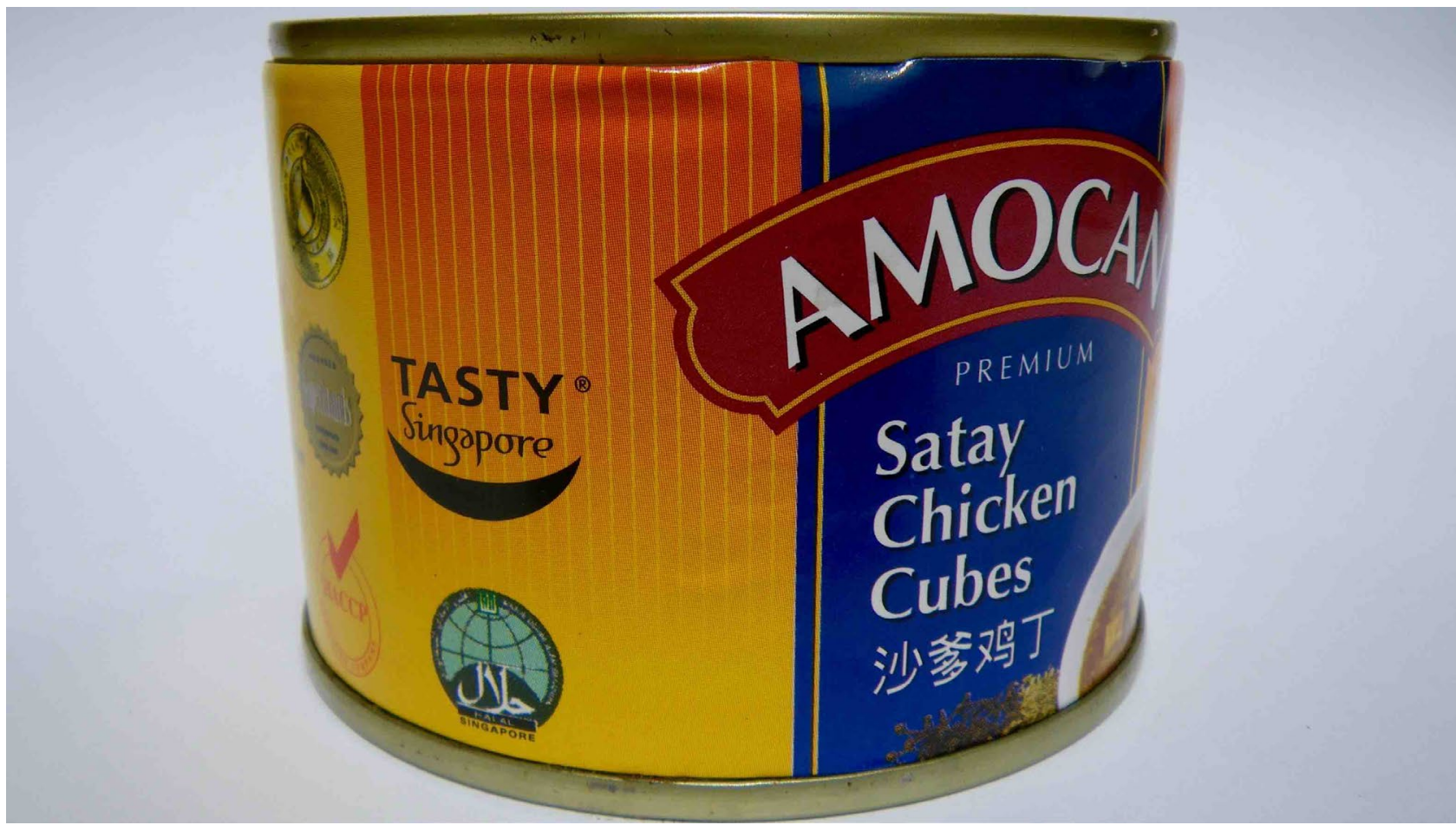

Figure 7. Amocan Satay chicken.

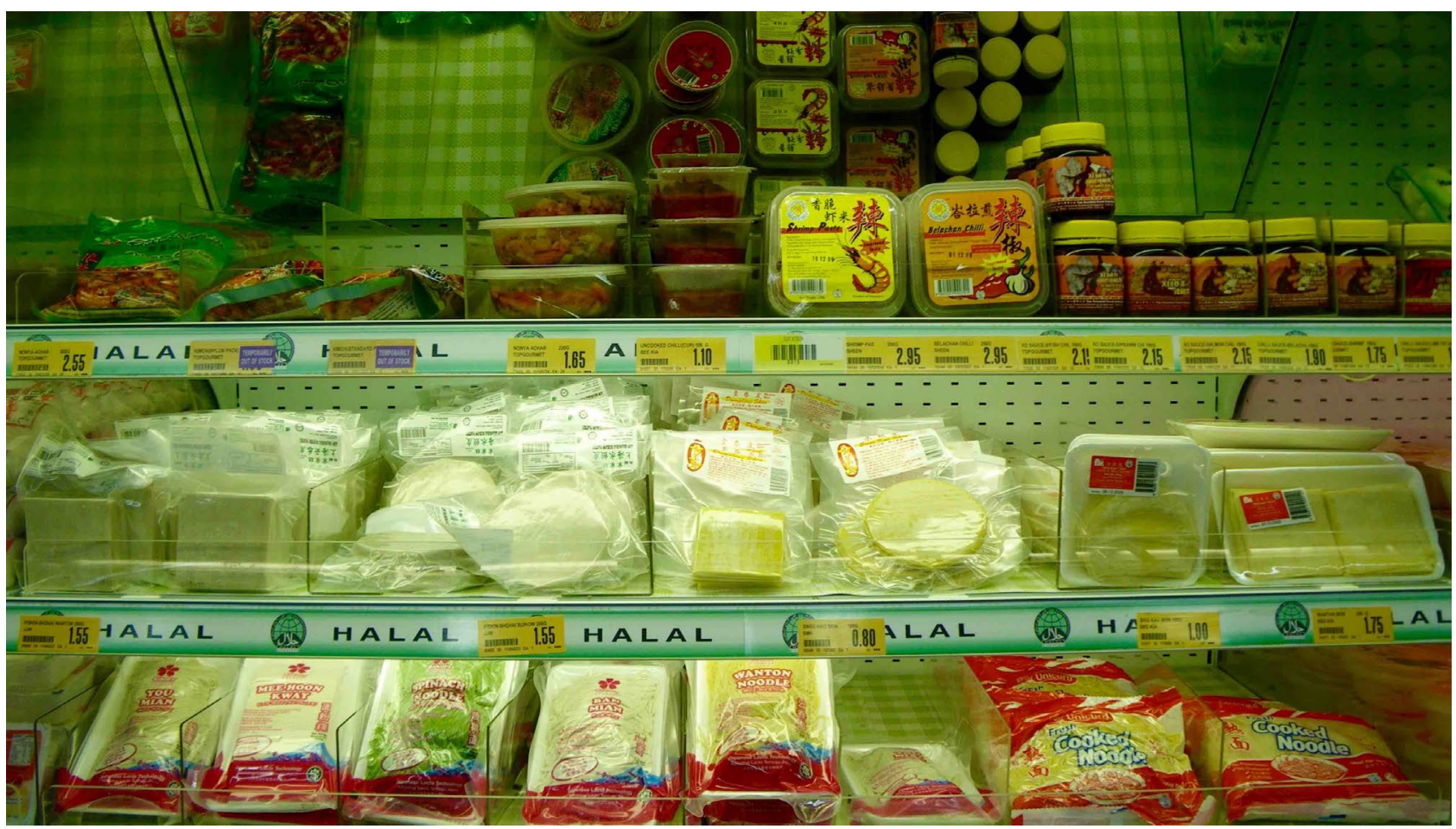

Figure 8. The halal counter. 


\section{Conclusive discussion}

Archive analysis showed that visual systems also have historical dimensions, that is, the state worked hard to promote halal logos as the most stable marker of Singapore's dedication to halal. Thus, halal logos are not only part of visual systems - they have also played a central role in the active construction and communication of a new Islamic visual system regulated by the state. Based on specific forms of legislation and audit regimes, this system now operates in the urban setting of Singapore and it is unlikely to be rolled back. Thus, visual systems signify that spaces have become standardized and that they are auditable. In this way, halal logos should be seen in the context of larger questions of power that convey differentiation, order, clarity, consistency and cleanliness. Halal logos and certificates in the public/national space are also "logos of the state." Audit culture and standardization make halal impersonal, and, in turn, this creates a need for third party visual assurance, which also has legal implications. The FairPrice case shows that in Singapore halal certification is fully centralized in MUIS. The standardization of halal in shops eases compliance for companies, but ironically compliance is causing halal requirements to intensify so that they cover more and more products and processes, that is, audit culture is driving control and self-control further into shops and restaurants.

My empirical exploration of logos in the Singaporean context showed how logos signify a new phase in logo development characterized by forms of religious regulation, certification, and standardization. Halal, as an element in visual systems, both conditions, and is conditioned by, the national context, politics, and power. This study also underlined that halal logos function as a localized form of Islamic branding in Singapore that is inseparable from religious ideology, even though in the overall national context of the Singaporean nation Muslims are a minority among the Chinese majority. Thus, ethics, power, marketing, politics/policies, and history in Singapore all inform visual systems, 
and in recent years this system has become ubiquitous: halal logos mark not only products and certificates, but most importantly, perhaps, restaurant, and shop spaces. As we have seen, many halal logos can be found on restaurant doors and this signifies that spaces outside restaurants may be considered non-halal or indeterminable at best. An example of this was the massive halal logo on a McDonald's outlet in Chinatown that I discussed as a form of McDonaldization of visual systems. Since McDonald's and many other multinational companies were halal certified in Singapore in the 1990s they have given shape to halal visual systems.

Standardization makes halal impersonal, and, in turn, this stresses the need for third party visual assurance that also has legal implications. Standardization of halal smoothens compliance for companies, but ironically compliance is also driving up halal requirements to cover more and more products and processes. In other words, audit culture pushes control and self-control further into businesses. Obviously, these transformations have a number of marketing implications. Firstly, the standardization of halal visual systems also works as a form of branding: businesses are very conscious about how halal logos fit the designs of product wrappings, facades and advertisements. Simultaneously, MUIS has centralized halal certification in Singapore so that the certification body can claim authority in the market nationally and abroad and the body also charges fees for certification. Thus, if a business wants to market/brand its products in Singapore, it has to comply with halal regulation and the standardization of visual systems. This leads me to the second point, that is the risks involved in the above processes of standardization. Not only smaller companies, but also multinationals such as McDonald's have become extremely sensitive to alerts made by consumers. For example, in 2010 McDonald's pulled a pig toy from its latest toy promotions in Singapore. The pig soft toy was expected to have been part of a 12-character Doraemon 
set depicting the animals of the Chinese zodiac calendar. But following complaints McDonald's decided not to include the pig toy to avoid offending Muslim customers. This move caused widespread controversy in Singapore (Straits Times, January 9, 2010) and concern that halal standardization was becoming excessive in a Muslim minority context. Thus, businesses must try to find a balance between halal compliance and what can be considered excessive standardization - especially in non-Muslim contexts. Lastly, following Tadajewski and Brownlie (2008) the standardization of halal visual systems should be seen in light of broader transformations between Islam and markets in Singapore and Southeast Asia. For example, during fieldwork a Manager from Singapore General Hospital explained to me that there is an increasing focus on public institutions such as hospitals and halal because Muslims from the Middle East, in particular, have become medical tourists. At the same time, Southeast Asia is also a region in which Islamic finance flourishes. With regard to public institutions as well as in banks Islamic visual systems signal that there is compliance with 'proper Islam consumption' (Fischer 2008).

Finally, logos play a central role in the visual systems of a nation, suggesting a further arena for the politics of ownership and protest, domination and resistance. Halal and halal logos are subject to novel forms of legality, with their specialized traditions, codes and practices, but also as cultural objects. The more halal proliferates globally as part of visual systems, the more technological modes and methods of production and traceability are becoming important for producers, traders, certifiers and consumers. An example of this is halal branding in the form of halal logos on packaged products. Another example is halal logos in industrialized food production and regulation: when I accompanied a halal inspector in a multinational biotech company he was very focused on visual aspects of the production processes as well as scrutinizing logos, certificates 
and accompanying documents (Fischer 2015). The increased focus on such methods to verify commodities as halal based on Islamized knowledge and technology constantly expands the requirements to cover new types of commodities and practices. At the same time, the fusion of religion and technology is inseparable from state/political support and funding. Both religious authorities and business are increasingly relying on halal logos as elements in visual systems which standardize, innovate and disseminate halal.

The results of this study are context-specific. Situational opportunities and constraints include the fact that Singapore exists in a double minority setting (Chinese are a majority in Singapore but a minority in the region, whereas Malays are a minority in Singapore but a strong majority in the immediate region). Consequently, the pervasiveness of standardized and regulated halal, and its centrality in visual systems, is largely due to Singapore's strategic location between the major markets for halal in neighboring Indonesia and Malaysia. Singapore's Muslim population is small and my research shows that many Muslims are relaxed about halal in their everyday food consumption. This also helps explain the organizational behavior, that is, multiple strategies and responses, among local actors when they try to comply with the state's promotion and management of halal.

While I have considered the Singaporean local context only, the global context is also essential to understanding halal as an element in visual systems in Singapore. As an example, a major food scandal in Indonesia in 2001 triggered a new phase of halal proliferation and regulation on a global scale. The Majelis Ulama Indonesia or Indonesian Ulemas Council (in English) (MUI), set up by the Indonesian state in 1975, accused a Japanese company, Ajinomoto, of using pork products in the production of the flavor enhancer monosodium glutamate and demanded that the Indonesian government take 
appropriate action. It was a serious accusation: if true, the company would have violated halal rules, which forbid Muslims from eating any pork or pork-derived products. As a consequence of the scandal, several of the company's employees were arrested, and a public apology was issued. It is most likely that the flavor enhancer did not contain any pork products; instead, the company conceded to having replaced, for economic reasons, a beef derivative with the pork derivative, bactosoytone, in the production process. Bactosoytone was used as a medium to cultivate bacteria that produce the enzymes necessary to make monosodium glutamate. As the company's products had previously been certified as halal by the MUI, the scandal seemed to undermine or question the legitimacy of these religious scholars in the eyes of millions of Muslim consumers. The scandal increased the global focus on third party halal certification and thus a standardized visual halal culture. The hype in Singapore was considerable: MUIS advised Muslims to be careful, and inspectors checked supermarkets for Ajinomoto products (The Straits Times, February 11, 2001). In a way, the scandal in Indonesia was a culmination of a longer process of promoting and managing halal in Singapore. Thus, following Johns (2006), national and global "omnibus" contexts together conditioned a whole range of behaviors and attitudes in the "discrete" context, that is, among MUIS, restaurants and shops. 


\section{References}

Agriculture and Agri-Food Canada. 2011. Global Halal Food Market. Ottawa: Agriculture and Agri-Food Canada.

Alserhan, B. A. 2010. “On Islamic Branding: Brands as Good Deeds.” Journal of Islamic Marketing 1(2): 101-106.

Arham, M. 2010. "Islamic Perspectives on Marketing." Journal of Islamic Marketing 1 (2): 149-164.

Baines P and Dixon C. 2003. Signs: Lettering in the Environment. New York: Harper Design.

Bennett, L. W. and Lagos, T. 2007. "Logo Logic: The Ups and Downs of Branded Political Communication." The ANNALS of the American Academy of Political and Social Science 611: 193-206.

Bergeaud-Blackler, F. 2007. "New Challenges for Islamic Ritual Slaughter: A European Perspective." Journal of Ethnic and Migration Studies 33(6): 965-80.

Bergeaud-Blackler, F., Fischer, J.and Lever, J. (eds). 2015. Halal Matters: Islam, Politics, and Markets in Global Perspective. New York: Routledge.

Brunsson, N. and Jakobsson, B. 2000. A World of Standards. Oxford and New York: Oxford University Press.

Burton, A. 2006. Archive Stories: Facts, Fictions, and the Writing of History. Durham: Duke University Press.

Busch L. 2000. "The Moral Economy of Grades and Standards." Journal of Rural Studies 16: $273-283$.

Chmielewska E. 2005. "Logos or the Resonance of Branding: Close Reading of the Iconosphere of Warsaw." Space and Culture, 8(4): 249-380.

Chua BH. 1995. Communitarian Ideology and Democracy in Singapore. London and New York: Routledge.

Comaroff J and Comaroff J. 1992. Ethnography and the Historical Imagination. Boulder: Westview Press.

Denny FM. 2006. An Introduction to Islam. Upper Saddle River: Pearson Prentice Hall. Evans K. 1992. "The Argument of Images: Historical Representation in Solidarity Underground Postage, 1981-87.” American Ethnologist, 19(4), 749-767.

Fanselow, F. S. 1990. "The Bazaar Economy or How Bizarre is the Bazaar Really?", MAN New Series 25(2): 250-265. 
Fischer, J. 2008. Proper Islamic Consumption: Shopping among the Malays in Modern Malaysia. Copenhagen: Nordic Institute of Asian Studies Press.

Fischer, J. 2011. The Halal Frontier: Muslim Consumers in a Globalized Religious Market. New York: Palgrave Macmillan.

Fischer, J. 2015. Islam, Standards and Technoscience: In Global Halal Zones. New York: Routledge.

Fischer, J, Lever J. and Bergeaud-Blackler, F. (Eds). 2015. Halal Matters: Islam, Politics and Markets in Global Perspective. London and New York: Routledge.

George C. 2006. Contentious Journalism and the Internet: Towards Democratic Discourse in Malaysia and Singapore. Singapore: Singapore University Press in Association with University of Washington Press.

Gray N. 1960. Lettering on Buildings. London: The Architectural Press London.

Gupta A. 1995. "Blurred boundaries: The Discourse of Corruption, the Culture of Politics, and the Imagined State. American Ethnologist 22(2), 375-402.

Henkin D. 1998. City Reading: Written Words and Public Spaces in Antebellum New York. New York: Columbia University Press.

Izberk-Bilgin, E. 2012. "Infidel Brands: Unveiling Alternative Meanings of Global Brands at the Nexus of Globalization, Consumer Culture, and Islamism." Journal of Consumer Research 39, 1-49.

Jafari, A. and Sandıkcı, Ö. 2015. “'Islamic' Consumers, Markets, and Marketing: A Critique of El-Bassiouny's (2014) 'The One-Billion-Plus Marginalization'.' Journal of Business Research, 68(12): 2676-2682.

Jafari, A. and Süerdem, A. 2012. "An Analysis of Material Consumption Culture in the Muslim World." Marketing Theory 12(1): 61-79.

Jafari, A. and Sand1kc1, Ö. 2016. "The Ontological Pitfalls of Islamic Exceptionalism: A Re-Inquiry on El-Bassiouny's $(2014,2015)$ Conceptualization of 'Islamic Marketing'. Journal of Business Research 69(3): 1175-1181.

Kadir S. 2004. "Islam, State, and Society in Singapore.” Inter-Asia Cultural Studies 5(3), $357-371$.

Kurtz H. 2005. "Reflections on the Iconography of Environmental Justice Activism." Area 37(1): 79-88.

Laki, I. 2016. "The Tangible Qualities of Organically-Sourced Products." Social Analysis (6)2: 21-38. 
Large M. 1991. "The Corporate Identity of the Canadian Government." Journal of Design History, 4(1), 31-42.

Lavin M. 2001. Clean New World: Culture, Politics, and Graphic Design. Massachusetts: MIT Press.

Leeman J and Modan G. 2009. "Commodified Language in Chinatown: A Contextualized Approach to Linguistic Landscape.” Journal of Sociolinguistics, 13(3): 332-362.

Lever, J. and Miele, M. 2012. "Growth of Halal Meat Markets in Europe: An Exploration of the Supply Side Theory of Religion." Journal of Rural Studies

28(4): 528-37.

Marcus GE. 1995. "Ethnography in/of the World System: The Emergence of Multi-Sited Ethnography." Annual Review of Anthropology 24: 95-117.

Mattern S. 2008. "Font of a Nation: Creating a National Graphic Identity for Qatar." Public Culture 20(3): 479-496.

Mauzy DK and Milne RS. 2002. Singapore Politics under the People's Action Party. London and New York: Routledge.

Mitchell WJ. 2005. Placing Words: Symbols, Space, and the City, Massachusetts: MIT Press.

Mohamed Z, Shamsudin MN, and Rezai G. 2013. "The Effect of Possessing Information About Halal Logo on Consumer Confidence in Malaysia." Journal of International Food \& Agribusiness Marketing 25(1), 73-86.

Mollerup P. 1999. Marks of Excellence: The History and Taxonomy of Trademarks, London: Phaidon Press.

Morphy H and Banks M. 1998. "Introduction: Rethinking Visual Anthropology." In Rethinking Visual Anthropology, edited by H. Morphy and M. Banks, 1-23. New Haven and London: Yale University Press.

Muhamad N., Leong VS, and Md Isa N. 2017. "Does the Country of Origin of a Halal Logo Matter? The Case of Packaged Food Purchases." Review of International Business and Strategy 27(4), 484-500.

NTUC FairPrice. 2009. News Release. Singapore: FairPrice.

Parkinson TL. 1975. "The Role of Seals and Certifications of Approval in Consumer Decision-Making." Journal of Consumer Affairs, 9(1): 9-14.

Pereira A. 2005. "Religiosity and Economic Development in Singapore." Journal of Contemporary Religion 20(2): 161-177. 
Power, M. 1999. The Audit Society: Rituals of Verification. Oxford: Oxford University Press.

Riaz MN and Chaudry MM. 2004. Halal Food Production. Boca Raton: CRC Press.

Ritzer G. 2006. “An Introduction to McDonaldization.” In Mcdonaldization: The Reader, edited by R. Ritzer, 4-24, Thousand Oaks: Pine Forge Press.

Sand1kc1, Ö. 2011. "Researching Islamic Marketing: Past and Future Perspectives." Journal of Islamic Marketing 2 (3): 246-258.

Shafiq A., Haque AKM., and Omar A. 2015. "Multiple Halal Logos and Malays' Beliefs: A Case of Mixed Signals." International Food Research Journal 22(4), 1727-1735.

Tadajewski, M. and Brownlie, D. (eds) (2008) Critical Marketing: Issues in Contemporary Marketing. Oxford: John Wiley \& Sons.

The Straits Times March 23, 1978. Deceptive halal label: council will press for prosecution.

The Straits Times July 3, 1981. MUIS asks for halal proof.

The Straits Times November 12, 1985. Signs say halal but food not so - MUIS.

The Straits Times May 30, 1991. PAP dialogue sessions for Malay-Muslims.

The Straits Times May 23, 1992. Date and halal marks for abattoir poultry from July 15.

The Straits Times July 12, 1992. Eleven abattoirs get permit from MUIS to slaughter halal chicken.

The Straits Times July 16, 1992. Labelling foul-up on start of abattoir poultry tagging.

The Straits Times June 29, 1992. When is it halal?

The Straits Times July 13, 1992. Sinar is Muslim-owned.

The Straits Times August 27, 1992. McDonald's food and drinks now halal.

The Straits Times May 13, 1994. Malay Village pulls out ads that said food is halal.

The Straits Times August 17, 1995. Get halal certification from MUIS.

The Straits Times August 21, 1995. The MUIS logo.

The Straits Times June 25, 1996. Going turkey with the bacon.

The Straits Times April 23, 1997. Burger King menu confuses Muslims.

The Straits Times April 1998. Changes will benefit others; June 28, 1998: AMLA-bill the changes it will bring about.

The Straits Times September 25, 1999. Surge in shops seeking to be certified halal.

The Straits Times September 13, 2006. Review law on halal cert misuse: Judge.

The Straits Times November 14, 2007. Tougher certification for halal items.

The Straits Times September 16, 2008. Muslim institutions to get more clout.

The Straits Times January 9, 2010. McDonald's pulls pig toy.

Süerdem, A. 2013. "Yes My Name is Ahmet, but Please Don't Target Me." Islamic Marketing: Marketing IslamTM?" Marketing Theory 13(4): 485-495.

Sutton J. 1965. Signs in Action. London: Studio Vista and New York: Reinhold Publishing Corporation.

Thomson Reuters. 2016. State of The Global Islamic Economy Report 2016/17.

Watson JL. 2006. "Transnationalism, Localization, and Fast Foods in East Asia." In Mcdonaldization: The Reader, edited by R. Ritzer, 292-305. Thousand Oaks: Pine Forge Press. 
Williams R. 1976. Keywords: A Vocabulary of Culture and Society. London: Fontana/Croon Helm.

Yao S. 2007. Singapore: The State and the Culture of Excess. Oxon: Routledge.

Zainal MF bin. 2009. MUIS Halal Certification: Local Causes, Global Impacts? BA

Thesis Dept. of Geography. Singapore: National University of Singapore.

Zhuang J. 2009. “See this City's Voice,” Singapore Architect 251: 152-155.

\footnotetext{
${ }^{1}$ The data can be accessed at: http://www.singstat.gov.sg/pubn/popn/c2010acr/key_demographic_trends.pdf

${ }^{2}$ AMLA can be accessed at: http://statutes.agc.gov.sg/.

${ }^{3}$ http://www.muis.gov.sg/cms/services/hal.aspx?id=1714
} 